\title{
The method of city venue betterment and integration based on plaza design of Xiao Nan cathedral

$$
\text { ZHAO Xiaofan }
$$

School of design and art ,Shenyang aerospace university, Shenyang, Liaoning China

zhaoxiaofan7724@163.com

Corresponding author Zhao Xiaofan

Keywords: city renewal, identity, accessibility , place

Abstract. This paper is to take Shenyang Xiao Nan cathedral plaza design as an example to discuss the betterment and integration method in functional area of a city. It comprises of the value, the methods, the processing and the efficiency of public space releasing. The result of the research is expected to provide a sample for the improvement on the functions of an old city with the reference for restoration of public space and methods of city betterment.

\author{
城市特色功能区修补与整合途径一小南教堂广场为例 \\ 赵晓凡 \\ 沈阳航空航天大学设计艺术学院, 沈阳, 辽宁, 中国 \\ zhaoxiaofan7724@163.com \\ 通讯作者: 赵晓凡
}

关键词：旧城更新；识别性；可达性；场所性

中文摘要. 本文以沈阳小南教堂前广场设计案例为基础, 来探讨城市特色的功能区的修补与 整合方法。包括价值理念, 技术方法, 推进过程, 公共空间释放功效等进行梳理。为当下老 旧城市建成区的功能提升与修复方法提供样本。为城市公共空间的修复与再造提出借鉴。

\section{1. 背景}

沈阳小南教堂区域, 是沈阳重要的文化与商业区域, 同时也是城市旅游, 市民游䟤的重 要公共空间。在城市中占据重要的作用。沈阳文化旅游的重要节点, 市民公共空间的重要载 体，闲暇生活的重要组成部分，文化，心灵的重要依托。

\section{1 教堂历史:}

1861年法国神父方若望(1805年-1878年)从营口来沈阳传教。1875年教堂开始兴建, 1878 年完成。1900年7月2日在庚子之乱中教堂被烧毁1909年用庚子赔款重建教堂, 1912年竣工, 法国人梁亨利设计。 


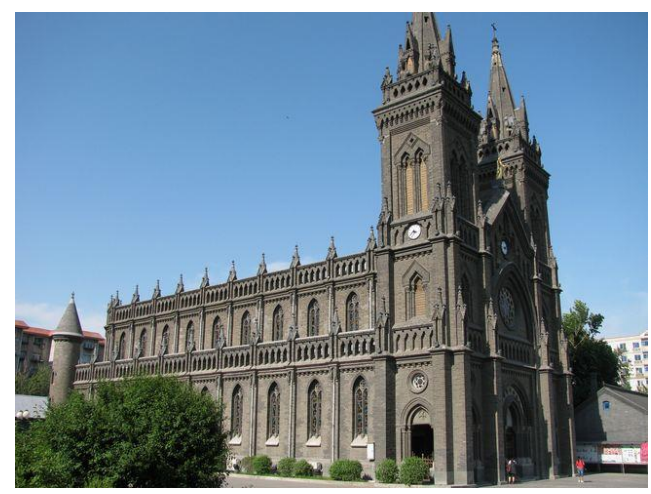

图1 小南教堂形制来源: 作者

\section{2 教堂形制:}

教堂坐北朝南, 双塔高40米, 进深54米, 用青砖砌筑, 正面中央部位是大玫瑰窗。这是 一座风格纯正的哥特式大教堂。1949年以前, 南关耶稣圣心主教座堂一直是沈阳的最高建筑 物。1988年被列为辽宁省文物保护单位。

\section{3 场地形制:}

教堂位于东院，坐北朝南，南北长66米，东西宽17米。砖混结构，青砖素面，正面顶部 突出有两个方锥形尖顶, 东西并列, 上部装饰有“十”字架。整体建筑格局沿袭了欧洲文艺复 兴时期的建筑形式, 是典型的哥特式建筑。教堂整体建筑围廓在东西80米长, 南北112米宽的 青砖院墙内，房屋占地面积3，213平方米，总面积9公顷。（如图1）

\section{2. 现状问题及目标}

\section{1 现状问题}

对现状环境梳理, 我们可以发现教堂前现状广场的公共空间并没有被充分利用, 结构老 化, 设施陈旧, 场地空间的可达性与可留性不强, 广场特色不明晰与教堂形象关系不协调, 缺乏整体连续性。广场功能单一可供人们参与的功能缺乏。问题主要集中在以下几点: (如 图2）1小南中心区物质老化, 结构衰退, 功能衰退, 物质损耗急需补偿。2大拆大建设, 城市 资源浪费, 城市文脉切断, 文物遭到破坏, 城市走向雷同, 特色风貌消失, 道路网微循环不 畅, 静态停车混乱, 广场与教堂空间协调性弱, 整体关系不明晰, 边围建筑立面形态混杂, 没 有处理好我和我们之间关系，城市设计一体化缺乏考虑。3 3 广场基面有效公共空间利用不高， 无障碍设施缺失，沈河区文化旅游节点作用未完全显现。

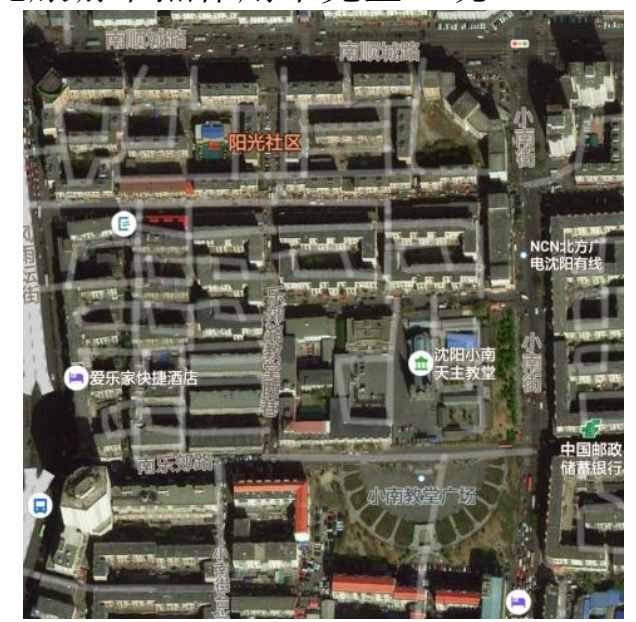

图2 小南教堂广场现状来源: 百度地图 


\section{2 目标}

其一，场域与公共的美学对话，完善广场功能，增加与教堂及周边环境的联系与融合。 其二, 充分利用地下空间, 解决周边缺乏停车场。其三, 最终形成与沈阳故宫, 大帅府, 慈 恩寺新的一体化旅游线路,旅游节点，文化节点。

\section{3. 公共空间再造及价值理念}

土地细分，街道友好，叠层立体空间，土地，空间利用混合.可达性，便利性，兼容性， 15分钟步行文化商业圈。可达性是促进货物及人员的流通, 重视安全与舒适的步行环境。便 利的通行依靠改建街道, 乃弥补机动交通的排他性。多样性表现为城市的功能为市民提供更 多样化的选择, 同时维系经济可行与工作选择, 同时为宜居和吸引力做贡献。兼容性是在一 体化设计的前提下, 统合城市各元素并保持视觉和谐的平衡力。并保持独特的场所感。适应 性是促进完整性和积极的改变。使街道, 街区适应新的用途, 促进旧城更新, 以达到更高的 开发强度和更优的环境标准。开发强度, 是人和场所更紧凑和更容易的集中, 同时增加公共 交通服务的可行性。识别性是一种独特的场所感, 使场所特色鲜明, 创造和保护城区的品质, 独特的个性通过维护和再利用历史建筑和高识别度的场所得以实现。系统性步行友好的交往 场所塑造，建立网络化，共享化，景观形态模式。

\section{4. 整合应对与技术方法: 特色功能区的修复}

\section{1 道路向街道转变}

需要打通该区域的断头路和丁字路, 来激发人的聚集, 体验和交往, 与交织的机会。在 一个高密度的地块中增加彼此联系的通路, 就会提供城市多样生活的可能。同时到达公共空 间的机会就大大增强。土地细分之后, 步行机会增强, 彼此联系的线性空间结合公共休息开 敞空间, 街道的氛围就显现出来了。同时拓宽外围城市道路的人行步道宽度, 与打通的内部 道路整体联系, 最终形成步行网络, 街道感应运而生。以环境行为的尺度进行限定街道之间 的距离及街道的尺度形成人性化的空间关系的密路网, 小街廓。这样富有历史感的公共“微空 间”得以显露，城市历史记忆片段得以留存。

\section{2 区域居住区向社区转变}

该区域范围内基本是老旧小区，现状小区老旧，底层空间基本是作为五爱商业区的商户 库房。内部人力交通及货运交通频繁。整体居住环境趋于恶化。这里主要体现的是居住适宜 性与商业环境及配套设施的冲突就问题。基于此, 居住区居住小区的基本模式并不适应这样 的高密度区域, 那如何保证地块内的居住环境同时满足商业配套设施要求呢, 以开敞的街区 营造商业网络, 以封闭的组团来实现居住环境质量。活力与宜居并举的思路来修复城市重点 的特色功能区。居住行为也会由单一的居住功能转化为邻里的生活交往功能。这种模式对老 旧传统的居住小区很强的适应性弹性, 组团的封闭可以通过住宅的沿街道加建门市的一二层 来实现, 同时也可以在内部边缘用景观植物围合实现, 也可通过带型的绿地公共休憩空间实 现, 用透空的景观墙来实现等。体现景观的多样性, 满足商业界面连续性的街道空间需求同 时满足居住组团内部空间的安宁性。 


\section{3 空间向场所转变}

以公共空间为媒介, 以城市环境行为为内在逻辑, 建构复杂的城市要素之间的系统关系。 增补城市设施欠账, 增加公共空间, 改善出行条件, 保护城市历史风貌, 同时塑造城市时代

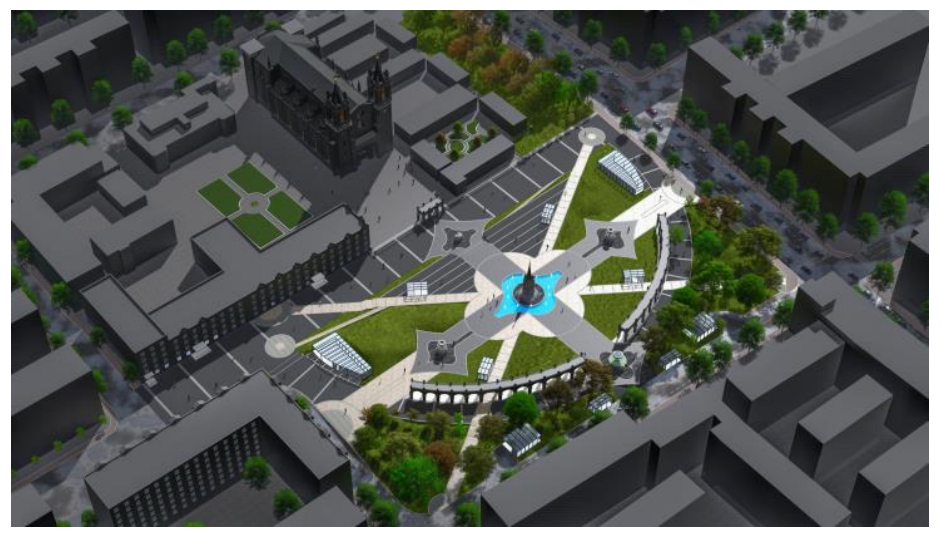

图3 小南教堂广场规划效果来源: 作者

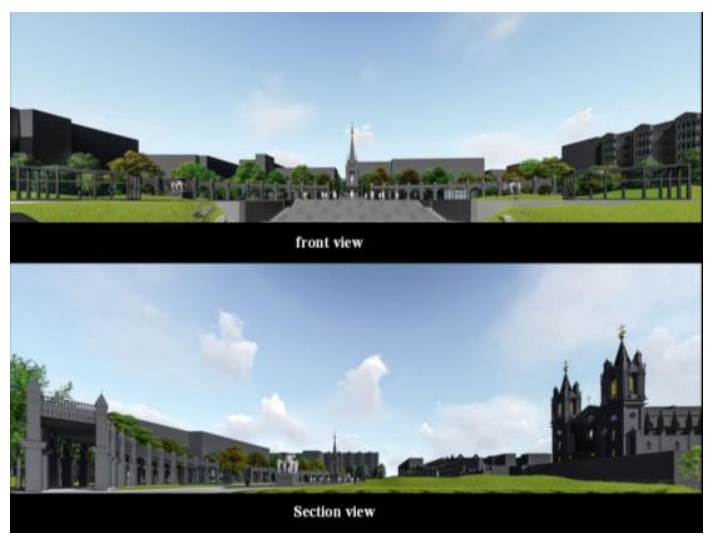

图4 小南教堂广场剖面效果来源: 作者

风貌。促进建筑, 街道空间, 天际线, 色彩, 与环境协调, 成为市民及游客的重要场所。通 过限定广场尺度来实现空间紧凑, 通过轴线关系与街道网改造来实现便利可达性, 通过多功 能的复合利用实现兼容性, 通过教堂本体现状空间与广场空间统合来实现易识别性, 环境品 质的亲和性, 通过场所尺度, 景观单元, 文化元素渗透来实现一体化特色, 景观视廊结合边 围建筑立面统合来实现，特色提升，文化品质与体验。赋予场所精神意义（如图3）。

\section{5. 广场公共空间释放途径: 特色功能区的空间再造}

\section{1 广场设计元素提取:}

内涵文化景观的呈现体现本体教堂文化的外溢与整体空间的渗透。通过该区域城市DNA 文化元素提取作为本案设计文化元素。主要体现在拉丁十字元素提取, 巴洛克形态元素提取, 重音元素提取。通过空间形态, 和文化符号形态共建可感知的场所。圣母, 圣子, 圣灵三位 一体，典型圣经故事再现，来实现充满爱的广场空间，和文化内核。（如图4）

\section{2 空间递进与景观层次}

通过边围, 基面, 和重音的处理, 形成生理, 心理, 精神的时空统一, 180度的观演教堂 形体空间与入画空间，360度的景观文化体验。多维的时空认知空间。空间层次处理主要体现 在以下几个方面1, 教堂场所空间与步行友好一体, 体现空间的可达性与可留性。2, 强调文 化内核, 公共性与市民性, 规划的广场提供相应的文化和休息设施满足市民的多功能需要。3, 教堂空间与广场空间一体化, 相互渗透。通过形态元素, 材料, 体量, 空间及色彩实现统一。 4, 巴洛克风格, 轴线及放射, 强调景深与重音。形成以教堂为中心的南北, 和东西的主要十 字性轴线, 放射性形成焦点的次要轴线, 以及统合半圆形的联系轴线。结合轴线形成字母功 能点。5, 叠层处理空间, 提高利用效率广场地下布置社会停车场, 满足静态交通需求, 提升 地面的环境质量。6, 注意景观层次及空间视廊, 形成20-30米的近景空间尺度, 80-100米的 景观场所尺度，以及300-400米的背景领域尺度关系。7, 满足环境容量及场所集散，形成以 公共空间及公共空间的关系, 满足游客集散, 婚纱摄影, 夜晚广场舞, 健步走, 小型体育锻 炼的需求空间。（如图5) 最终形成与故宫, 大帅府, 慈恩寺新的一体化旅游线路。旅游节点, 文化节点, 特色商业节点。 


\section{3 公共空间再造}

可达性是促进货物及人员的流通，重视安全与舒适的步行环境。便利的通行依靠改建街 道, 乃弥补机动交通的排他性。多样性表现为城市的功能为市民提供更多样化的选择, 同时 维系经济可行与工作选择, 同时为宜居和吸引力做贡献。兼容性, 是在一体化设计的前提下, 统合城市各元素并保持视觉和谐的平衡力。并保持独特的场所感。适应性是促进完整性和积 极的改变。使街道, 街区适应新的用途, 促进旧城更新, 以达到更高的开发强度和更优的环 境标准。开发强度，是人和场所更紧凑和更容易的集中，同时增加公共交通服务的可行性。 识别性是一种独特的场所感, 使场所特色鲜明, 创造和保护城区的品质, 独特的个性通过维 护和再利用历史建筑和高识别度的场所得以实现。

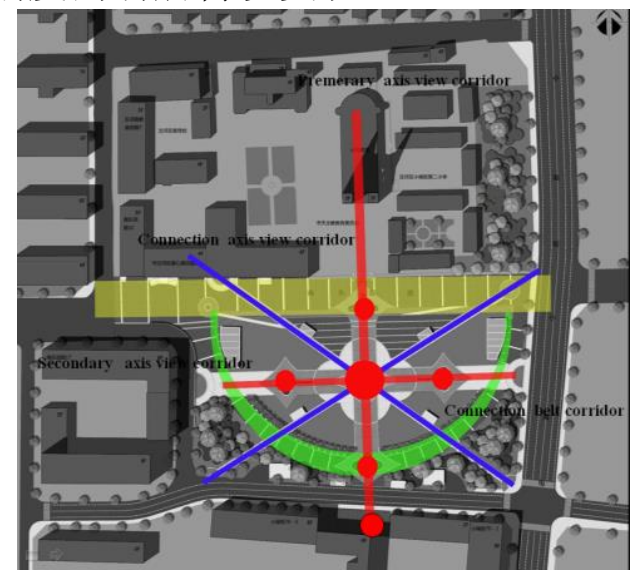

图5 小南教堂广场结构关系来源: 作者

\section{6. 启示}

对于旧区区公共空间设计而言，要综合考虑地块的现状因素，用系统的思维进行空间梳 理，运用“空间之间”的相互联系进行研究，避免单一思路 “储藏室”的各自为政的来解决问题。 城市特色区域的修复和再造是当下中国城市内公共空间充分释放的必然需求, 高开发强度的 城市内核再造是必然出路。再开发城市公共空间时我们要运用更加综合的方法应对, 不仅仅 是场地设计，而是区域的系统连接，做到可达性，多样性，兼容性，识别性的综合。

\section{致谢}

辽宁省教育厅人文社科课题资助项目《城市公共空间建设问题及形态对策研究》的阶段 性成果。项目编号：L201647

\section{References}

[1] John Lund Kriken. City Building: Nine Planning Principles for the twenty-century [M] Princeton Architectural Press,2010.03

[2] Wang.Yi,and Lu.Jiwei. city renewal and the construction of special dynamic zone [J].New Architecture,2016(1).

[3] Ministry of housing and construction. guiding opinions on strengthening ecological restoration and urban betterment. 2017,03,19 